\title{
The Relationship Between Teachers' Workloads on Teaching Performance: A Case Study on Teachers Of Bilingual Class At A Private Islamic Boarding School
}

\author{
Mohammad Umar Fakhrudin ${ }^{1}$ Erna Andriyanti ${ }^{2}$ \\ \{mohammadumar.2019@student.uny.ac.id ${ }^{1}$ erna.amdriyanti@uny.ac.id ${ }^{2}$ \} \\ Magister Program of Yogyakarta State University, Yogyakarta, 55281, Indonesia ${ }^{1}$, Magister \\ Program of Yogyakarta State University, Yogyakarta, 55281, Indonesia ${ }^{2}$
}

\begin{abstract}
Modern Islamic boarding school has become one of the trends to study since it offers teaching Islamic subjects through bilingual programs: English and Arabic. Concerning the use of English program, either the teachers or students must use the language either inside or outside the classroom. To run the program, the teachers must be wellqualified for they must be both teachers in the classroom and supervisors in the bilingual dormitory. These demands create overloaded work for the teachers. Thus, this study aims to identify the impact of Islamic boarding school teachers' workload. A descriptive case study was employed in this study. Then, the data were obtained through the interview to bilingual English teachers and direct observation. The result shows that bilingual teachers' workloads negatively affected their teaching performance quality; they have limited time to do self-reflection and prepare a clear objective of the lesson and the expected outcome.
\end{abstract}

Keywords: Teachers' Workloads, Bilingual Program, Teaching Performance

\section{Introduction}

A bilingual program in pesantren has become one of the trends to study since it offers to teach Islamic, science, and social courses through bilingual programs. A pesantren itself in Indonesia has been significantly contributing to education across the country since the colonization era. As one of the oldest Indonesian education systems, schools in pesantren have taught English as compulsory subjects in its national curriculum (Daulay, 2009; Kamil, Mukminin, \& Kasim, 2014; Sofwan \& Habibi, 2016). A pesantren is like a community completed with complex, mosque, and boarding facilities in which santri (students) and ustadz (teachers) learn, sleep, eat, and communicate the whole day (Buang, 2007; Nilan, 2007; Srimulyani, 2007). Daulay (2009) states that most students in pesantren spend fully 24 hours a day communicating, interacting, and socializing with their society, friends, and teachers. This reality brings about various situations and phenomena both academically and socially. From that 
behaviors, many pesantren build a bilingual program to upgrade the students' competence, especially for their foreign language proficiency.

Bilingual education is an educational system emphasizing the use of both students' native language and English in the teaching-learning and the students' daily activity (Martin \& Loomis, 2014). For several decades, the practice of bilingual programs concerning the use of English as the target language is well established (Margana, 2015; Ozfidan et al., 2018). Margana (2015) adds that this also happens in Indonesia to make Indonesians more qualified and competitive citizens who can deal with global communication practices, intercultural awareness, and social international perspectives and contexts. English is chosen in the bilingual program as it is universally used as a communication tool either in the spoken or in the written form in the fields of education, technology, business, economy, tourism, etc.

Further, the program is also applied in Indonesian modern Islamic boarding schools. Islamic boarding school is an educational institution that was firstly focused on Islamic development by teaching Islamic thought and Arabic. It was then transformed and developed by implementing two foreign languages, Arabic and English, in teaching and learning and used as students' daily communication language (Bin Tahir, 2017). He adds that students are obliged to use foreign languages to improve their knowledge in Islamic studies and expand their language proficiency. To run the program, most modern Islamic boarding schools apply three kinds of curriculum to reach traditional and modern education objectives. They are curriculum of Kemendikbud (Ministry of Education and Culture), the curriculum of Kemenag (Ministry of Religion Affairs), and the curriculum of pesantren (Bin Tahir, 2011).

However, implementing the bilingual program in modern Islamic boarding schools raises an overloaded burden to the teachers since the teachers must involve themselves in different activities, either academic or non-academic activities outside of school hours. The activities are being a supervisor of organization, supervisor of multilingual or multilingual room, and official of coach of English competition. Those duties may create less optimum teaching and learning activities. Hargreaves (1992) states that work intensification represents one of the most tangible ways educational workers' work privileges are eroded. The teachers who get intensification mean they work like laborers who only reach the company's target. The teachers who do not have time for self-reflection cause quality reduction. Another theory is explained by Farber's theory of Burn out; most education practitioners get a higher emotional overload until they get stuck. Teachers who are emotionally and physically exhausted are irritable, anxious, and angry. He states that to be burnt out means being less enthusiastic in planning classes and feeling less sympathetic to the students. There will be no instruction that can be efficiently and effectively conducted over a long period if teachers carry on solemn teaching. Timpane as cited by Ayuman (1995), explains the effect of teachers' burnout. The term is used to describe and often excuse many teachers' inability to teach the classroom adequately. Further, burnout with all its symptoms will not quickly or easily disappear since it is in the profound and complicated psychological conclusion that their work is not productive. Referring to this, burn out is a substantial obstacle to educational reform and improvement at least for sensually affected personals and groups in schools. It goes without saying that burnout negatively affects teachers' performance in teaching. 
Teaching performance is one of the most crucial factors in teaching since it is how the teachers deliver their teaching or lectures to the students. A quality lecture should provide seven criteria to fulfill, according to MacGregor (2007). They are i) a clear objective of the lesson as well as the expected outcome, ii) building background by integrating concepts to students background, past learning, and critical vocabularies, iii) a clear structural idea to all students and allows them to have different pathways based on their needs, iv) using various strategies of questioning to stimulate and encourage students' development of critical thinking, problem-solving and performance skill, v) providing an adequate time for the students to give a response, vi) employing instructional approaches aimed to meet the needs of diversified learners, and vii) using a good instruction to meet the proficiency level of all the students in a classroom. In short, to be good teachers having a good performance, they should have good classroom management.

Classroom management is a crucial notion in education for teachers, lecturers, and all aspects in educational fields. There are students' characteristics, teachers efficacy, environmental situation, and students' achievement standards becoming influential classroom management factors (Baker, Lang, \& Lawson, 2002; Fowler \& Sarap, 2010; Kaya Donmez, 2009). In the Indonesian context, classroom management means a set of techniques and skills that let teachers control students effectively to create a positive learning environment for all students (Ministry of National Education, 2013).

To deal with this phenomenon, observation and interviews with three English teachers teaching and staying in modern Islamic boarding school will be conducted to analyze how their workload affects their teaching quality in the class. Thus, this paper is aimed at identifying the impact of Islamic boarding school teachers' workloads on their teaching performance quality. This study is expected to give the readers general overview of the effect of bilingual English teachers' workload on their performance.

\section{Methodology}

This study is a case study. The researchers use the theory by Creswell (2014) that this kind of study is interpretative research requiring the researchers to engage with the participants to experience the real situation.

The researchers conducted this research in the bilingual program of a private Islamic Senior High School in Brebes. There are three English teachers of this program becoming the sample of this research since they are assumed to have more workloads than other teachers as they have a duty both in the school and dormitory.

To obtain the data, observation, and interviews were conducted. The researchers believe that qualitative observations are the processes where the researcher takes field notes on individuals' behavior and activities at the research site (Creswell, 2014). In this case, the researcher wrote field notes of the teachers' activities either in the classroom or in the dormitory. Moreover, the researchers employed the semistructured interview by preparing some questions as a guide before interviewing the interviewee, and some addition to questions will be developed on the spot based on the participants' answers. It was taken to confirm what had been observed and provide more detail and historical information from the participants.

\section{Result and Discussion}

\section{1 Results on Interview}


The researchers interviewed three English teachers teaching in that program. To explore the teachers' workload affecting their teaching performance, the researchers divided two kinds of questions. The first one is question to ask their workloads, and the one is to ask their performance. Asking the teachers' workload, the researchers prepare three main question that then being elaborated while interviewing. They are:

1. How many hours do you teach in each week?

2. Do you have other school duties beside teaching?

3. Do you have other duties outside of the school?

Then, there are seven questions taken from the McGregor theory to know the teachers' teaching performance in the classroom. The questions are as follows:

1. Do you present a clear objective of the lesson as well as the expected outcome?

2. Do you build background by integrating concepts to students background, past learning and key vocabularies?

3. Do you give a clear structural idea to all students and allows them to have different pathways based on their needs?

4. Do you use a various strategies of questioning to stimulate and encourage students' development of critical thinking, problem solving and performance skill?

5. Do you provide an adequate time for the students to give response?

6. Do you instructional approaches aimed to meet the needs of diversified learners?

7. Do you use a well instruction to meet the proficiency level of all the students in a classroom?

In this research, the reasearchers labeled the teachers by T1, T2, and T3. Regarding the workloads, here are the responses:

1. Teaching hours

T1:

"In a week, my schedule to teach is around 44 hours if I'm not mistaken. It's quite hard for me to be on time to come to the class becuase of having no space." T2:

"I think because this is bilingual program so the class for English and Arabis is quite much. I have around 56 hours in week. Fantastic, right?"

T3:

"I am here a new teacher, and I was surprised to know my class since I was given 32 hours in a week. For me as the new one, honestly it's quite hard."

2. Other school duties

$\mathrm{T} 1$ :

"There are two main duties to do like being a coach in for English competitions, the committee of school events. Actually, they are not that hard, but those two duties require me to spend more time that sometimes I cannot do especially for being coach. To train the students, I need to spare a lot of time after finishing teaching. Students will finish their class at around 3.30 PM, and I still need to stay in the school to train them. But for this far, I enjoy the process even exhausting."

T2: 
"With those many hours I have. I still have several things to do in school. I'm one of the official coaches of English competitions. Then becoming a school committee events, even sometimes I'm the one chosen to be the chief of the event organizers. And maybe the hardest one is becoming a vice principal focusing on students' affairs. It's quite hard for me since I feel that I'm still too young to be so, having insufficient experience to solve several complex problems the students and schools face. Being in that position also gets me to be the head supervisors of all students' organization. Maybe you can imagine how I'm trying to survive everyday when I have 56 hours in a week, and still have to do those duties."

T3:

"I think I don't have that much burden like my two seniors. My duties are only the coach of Englsh Competitions and the supervisor of English club. Only two, but sometimes I can't deal with those since I'm still not that good in the time management."

3. Duties outside of the school

T1:

"Yes, I do. Becoming a supervisor for the girls' bilingual dormitory. I stay with my students, even my room is right beside their rooms."

$\mathrm{T} 2$ :

"I'm one of the supervisors of bilingual dormitory for boys. It means that I have to accompany my students for almost 24 hours, in the school and in their rooms. The students frequesntly come to my room to ask the materials that they haven't understood, or sometimes ask about the words to say that they haven't known. Besides that, we, supervisors, need to take care of their health."

T3:

"I guess our duties are the same, being a supervisor or a bilingual dormatiory that makes us spend our whole day with the students. So this far, I enjoy it maybe because I have no more workloads like other two supervisors."

Then, the following in the responses of the interview towards teachers' teaching performance in the classroom.

1. Presenting a clear objective of the lesson

T1:

"I try my best to always tell them about what is going to be discussed, and the objectives of it. However, sometimes I feel having no sufficient time or maybe just because of feeling so hectic, then I don't tell the objectives clearly. Those 44 hours do affect on my focus."

T2:

"Sure! I always tell the objectives of the lesson to students clearly. Unfortunately, due to too many duties I need to fix, sometimes I leave my class, and only giving them an assignment. But, like I said just now that if I entered to the class, then I would present my objectives of the lesson clearly."

T3:

"Yes. Again and again, maybe because I'm a new teacher so I'm still trying to be ideal and perfect to teach. Usually, after opening the class, I state the objective of the lesso going to learn."

2. Building background 
T1:

"Of course. In my class, the students have to be able to think critically so I really utilize the time to build or elicit the students' critical thinking. Unfortunately, sometimes other duties require me to leave the class. So, I just instruct them to do assignment of discussion."

T2:

"Yes. If I can say, it's my favorite part because the discussion starts in this points. Students are giving their ideas regarding the issues I mention. However, It's hard for me to manage my time that makes me either leave the class or come late to the class. Fortunately, my students understand my condition well." T3:

"Yes, but to be hinest, it's quite hard for me to with this since they are really active when I give them an issue to brainstorm."

3. Giving a clear instructional idea

T1:

"Not really. The problem is still the same, time. Having no enough time to find the references or sources. So, I the one for all. That's my bad",

T2:

"For this one, unfortunately, no. Actually I always try my best to give my best to my students. If I have no many things to do, I'll give what they need. The reality is that I even cannot check one by one whether they understand what I explain. I guess many of them are still confused as I give one idea for different students.”

T3:

"Sometimes yes, sometimes no. Sometimes I have no more idea to give more ideas to them."

4. Using various strategies of questioning

$\mathrm{T} 1$ :

"Yes, I do, but not that much."

T2:

"Sure! As I said before that eliciting students' critical thinking is my favorite part. I love to encourage them to be able to think critically and solve the poblems. Even sometimes in this part, the students will have debate."

T3:

"Not really. That's my bad not to elicit their critical thinking well since I'm still laking of experiences."

5. Providing an adequate time for the students to give response

T1:

"Yes. In the end of the class, I let students give renponses and summarize what they learnt. However, sometimes I run out of the time since I come to the class late."

T2:

"Sure. I always get my students to say what they understand and they haven't understood."

T3:

"Yes. But honestly sometimes I'm getting afraid having too many questions from them because they have a very high curiousity." 
6. Employing instructional approaches

T1:

"I use an instructional approach but I'm not that creative to make various approaches due to having no time to do so."

T2:

"I do, even I rarely make myself become the center of the class. However, it's bothered by other duties that sometimes make me blank in the class."

T3:

“That's me. I'm still so spirit to implement what I've got from the university. But, the problem is sometimes I can't make myself in into the approaches implemented."

7. Using a well instruction to meet the proficiency level

T1:

"Yes. To train the students' proficiency, I have a program called one day one student. This program requires the students to speak up for whatever they want. They may telling their own experiences, ambitions, etc."

T2:

"I don't know whether it's what it means. I always have 15 minutes the review the previous materials before learning the new ones. In the review, I have my students speak up, create sentences, give some conditions, do rebuttal, etc. This is aimed at eliciting their critical thinking and practicing their English contextually. It works if I'm not late and if I have no other duties to do, but frequently I have several things to do."

T3:

"Not really I guess since I feel that I'm still becoming the center of the class."

\section{2 Results on Observation}

Weekly Program. Based on the observation conducted, the researchers found that the bilingual students have weekly programs held on every Tuesday and Thursday night. This program aimed at practicing students' speaking proficiency by performing several English performances like storytelling, speech, debate, etc. In this activity, the supervisors were invited to be the judges to give feedback on the students' performances. The researchers found that the supervisors evaluated the students' performance in detail; pronunciation, stressing, grammar, and gestures. This activity ended at 10.00 PM.

Parents' Customer Services. Besides academic affairs, the supervisors also had to be able to be the Students' customer service for their parents. Since the students stayed far away from their parents, parents frequently asked their children's condition to supervisors. What the researchers saw was parents sometimes did not consider the time to phone the supervisors. The researchers found that the supervisors received calls from students' parents at 10.30 PM.

Health Care. Another duty to do by the supervisors was taking care of the students' health. The supervisors had to know who was getting sick and still stayed at the dorm and who was sick and went home. 
Students' Counselors. The students' counselors mean that the supervisors had to be ready when they wanted to consult about their problems, either academic and non-academics. The researchers found two students telling their private problem, a family problem until they cried. The supervisors looked so patient to calm them down.

\section{Conclusion}

This case study is aimed at identifying the impact of Islamic boarding school teachers' workloads on their teaching performance quality. Implementing the bilingual program in modern Islamic boarding schools raises an overloaded burden to the teachers since the teachers must involve themselves in different activities, either academic or non-academic activities outside of school hours. The activities are being a supervisor of organization, supervisor of multilingual or multilingual room, and official of coach of English competition. From the findings above, it that the overloaded works belong to the three English teachers affected negatively their teaching performance, proven by McGregor's theory (2017).

\section{References}

[1] Ayman, Bernardita C. 1995. "Teachers' Workload of Intermediate and Secondary Schools: Implications to School Administrators." Unpublished Master's Thesis. Saint Louis University, Baguio, City.

[2] Baker, C. (2006). Foundations of bilingual education and bilingualism. Clevedon: Multilingual Matters.

[3] Baker, W. P., Lang, M., \& Lawson, A. E. (2002). Classroom management for successful student inquiry. The Clearing House, 75(5), 248-252.

[4] Ball, P. 2006. Defining CLIL parameters. Retrieved from http://www.onestopenglish.com/clil/methodology/articles/ June 2012.

[5] Bell, L., \& Stevenson, H. (2006). Education policy: Process, themes, and impact. London: Routledge.

[6] Bin Tahir, S. Z. (2017). Multilingual teaching and learning at pesantren schools in Indonesia. Asian EFL Journal, 74-94.

[7] Canagarajah, A. S. (2007). Lingua franca English, multilingual communities, and language acquisition. Modern Language Journal, 91, 921-937.

[8] Cardno, C. \& Howse, J. (2005). The role and management development needs of secondary principals in Tonga and the Fiji Islands, International Studies in Educational Administration 33(3): 34-44.

[9] Cenoz, J., \& Gorter, D. (2011). A holistic Approach to Multilingual Education: Introduction. The Modern Language Journal, 95, 339-343.

[10] Creswell, W. John. (2009). Research design, third edition. USA: Sage Publication, Inc.

[11] Dulay, H. C. \& Burt, M. K. (1974). Natural sequence in child second language acquisition. Language Learning, 24, 37-53.

[12] Fowler, J., \& Şaraplı, O. (2010). Classroom management: What ELT students expect. Procedia Social and Behavioral Sciences, 3, 94-97. 
[13] Gay, L. R, Mills, G, and Airasian, P. (2006). Educational Research; Competencies for Analysis and Applications. Eight Edition. New Jersey; Pearson Prentice Hall.

[14] Hargreaves, A. (1992). Time and teachers' work: An analysis of the intensification thesis. Teachers College Record, 94, 87-108.

[15] Janina Brutt-Griffler \& Eunjee Jang (2019): Dual language programs: an exploration of bilingual students' academic achievement, language proficiencies and engagement using a mixed methods approach, International Journal of Bilingual Education and Bilingualism, DOI: $10.1080 / 13670050.2019 .1616670$

[16] Kaya, A., \& Dönmez, B. (2009). An evaluation of the classroom management approaches of the class teachers implementing constructivist learning approach. Procedia Social and Behavioral Sciences, 1, 575-583.

[17] Kemendikbud. (2013). Pengembangan Kurikulum 2013 (2013 Curriculum development). Kementrian Pendidikan dan Kebudayaan: Indonesia.

[18] Kramsch, C. (2006). From communicative competence to symbolic competence. Modern Language Journal, 90, 249-252.

[19] Lingam, G., Lingam, N., \& Sharma, L. (2017). Educational Reforms and Implications on Teachers' World of Work: Perspective of Fijian Primary Teachers. Australian Journal of Teacher Education, 42(1), 19-35.

[20] Margana. (2015). Establishing English-Indonesian in Indonesia: From Theory to Practice. RAJournal of Applied Research, 1(10), 365-374.

[21] Martin-Rhee, M. \& Bialystok, E. (2008). The development of two types of inhibitory control in monolingual and bilingual children. Bilingualism: Language and Cognition, 11 (1), 81-9. doi: 10.1017/S136672890700322.

[22] McGregor, D. (2007). Developing Thinking Developing Learning: A guide to Thinking Skills in Education, Berkshire: Open University Press.

[23] Mouw, T. and Xie, Y. (2011). Bilingualism and the academic achievement of first and second generation Asian Americans: Accomodation with or wthout assimilation. American sosiological review, Vol 64 no: 2.

[24] Ozfidan, et. al. (2018). Investigating Attitudes towards a Bilingual Education Curriculum: A Scale Development Study. Revista de Cercetare si Interventie sociala, 62. 9-20.

[25] Stevenson, H. (2007). Restructuring teachers' work and trade union responses in England: Bargaining for change. American Educational Research Journal, 44(2), 224-251. https://doi.org/10.3102/0002831207302194

[26] Sungalia, H. (1990). Organisations alive! Have we at least found the key to a science of educational administration, Studies in Educational Administration, (52), 1-32. 